\title{
PEMODELAN SPASIAL UNTUK PEMBUATAN PETA RAWAN BANJIR DAN PETA TINGKAT RISIKO BANJIR BENGAWAN SOLO DI KOTA SURAKARTA
}

\author{
Toto Cahyono $^{1}$, M. Pramono Hadi ${ }^{2}$, dan Djati Mardiatno
}

Fakultas Geografi, Universitas Gadjah Mada, Yogyakarta, Indonesia ${ }^{1,2,3}$

totocahyono@gmail.com

Diterima : April 2013; Direvisi : September 2013.; Dipubikasikan: 31 Maret 2016

\begin{abstract}
ABSTRAK Penelitian ini bertujuan untuk melakukan pemodelan spasial untuk menyusun Peta Bahaya Banjir dan Peta Tingkat Risiko Banjir akibat luapan Bengawan Solo di Kota Surakarta. Lokasi penelitian meliputi penggal alur Bengawan Solo di wilayah Kota Surakarta. Metode penelitian yaitu dengan analisis hidrograf, pemodelan banjir, analisis potensi bahaya banjir, analisis kerentanan banjir, dan analisis tingkat risiko banjir. Analisis hidrograf dilakukan dengan menghitung debit puncak rancangan, analisis geometrik sungai, dan analisis karakteristik banjir. Pemodelan spasial banjir menggunakan perangkat lunak ArcView dengan ekstensi HEC-GeoRAS dan perangkat lunak hidrologi HEC-RAS. Analisis potensi bahaya banjir dari peta genangan hasil pemodelan spasial dengan input debit puncak rancangan banjir periode ulang 60. Analisis kerentanan dengan identifikasi elemen yang berisiko pada peta penggunaan lahan daerah bahaya. Analisis tingkat risiko dilakukan dengan cara overlay peta bahaya dan peta kerentanan banjir. Perangkat lunak ArcView 3.3 dengan ekstensi HEC-GeoRAS mampu untuk melakukan pemodelan banjir dengan tingkat validasi yang tinggi. Validasi dilakukan dengan membandingkan kedalaman maksimum hasil pemodelan dengan hasil perhitungan debit puncak rancangan. Nilai perbedaan antara 0,68\% - 4,54\%. Meskipun secara kuantitatif peta model bahaya banjir rancangan sesudah pelurusan lebih luas daripada sebelum pelurusan, tetapi berdasarkan uji statistik penambahan luas tersebut tidak berbeda signifikan. Dari peta tingkat risiko banjir diketahui Kelurahan Sewu, Semanggi, Sangkrah dan Gandekan mempunyai potensi risiko banjir tertinggi di Kota Surakarta.
\end{abstract}

Kata kunci: bahaya banjir; kerentanan banjir; Kota Surakarta; pemodelan spasial; risiko banjir.

ABSTRACT This research is intended to perform flood modelling in Bengawan Solo River in order to develop flood hazard map, flood vulnerability map, and flood risk map as a result of overflow of such river in Surakarta City. The research area covers cut-off channel of Bengawan Solo in Surakarta City. The research was conducted by applying hydrograph analysis, flood modelling, flood hazard analysis, flood susceptibility analysis, and flood risk analysis. Hydrograph analysis was executed by calculating peak discharge designed, analysis of river geometric, and analysis of flood characteristic. Flood spatial modelling was done by means of ArcView with HEC-GeoRAS extention and hydrological software HEC-RAS. Flood hazard analysis was obtained by spatial modelling of flood inundation map with returned period of peak discharge designed of 60. Flood vulnerability analysis was derived from land use map used to identify risk element which exists in prone area. Flood risk analysis was carried out by overlying flood hazard map and flood susceptibility map. ArcView with HEC-GeoRAS extention and HEC-RAS was able to perform high validation of flood modelling. The validation was done by comparing maximum depth of the model and estimated peak discharge with different percentage $0.86 \%-4.54 \%$. Even the estimated flood hazard after river streamlining was wider than before, statistical analysis proves that different width of it was not significance. It means of river streamlining didn't influence the wide of flood hazard area. Sewu, Semanggi, Sangkrah, and Gandekan Sub District has the highest risk of flood in Surakarta City.

Key words: flood hazard; flood vulnerability; Surakarta City; spatial modelling; flood risk.

\section{PENDAHULUAN}

Penelitian ini berlatarbelakang kejadian banjir di Kota Surakarta yang terjadi pada tahun 1966, 1968,1973, 1974, 1975, 1982, 2007 dan tahun 2009. Debit banjir Bengawan Solo pada tanggal 26 Desember 2007 mencapai $2057 \mathrm{~m} 3 / \mathrm{s}$, jauh lebih tinggi dari kapasitas maksimal Bengawan Solo sebesar 1500 m3/detik, (BBWS Bengawan Solo, 2008). Meskipun usaha penanganan banjir Bengawan Solo telah dilakukan pada ahun 1982 dengan cara pembuatan tanggul dan tahun 1992 dengan cara pelurusan sungai dan sudetan, namun kejadian banjir masih terulang lagi tahun 2007 dan 2009.

Pelurusan Bengawan Solo tidak hanya mengubah bentuk morfologi sungai meander menjadi hampir lurus atau parabola, tetapi juga telah memotong panjang sungai dari $50 \mathrm{~km}$ menjadi $33 \mathrm{~km}$ antara Bendung Colo di perbatasan Kabupaten Wonogiri dan Kabupate Sukoharjo hingga jembatan Semanggi di kota Surakarta (perbatasan Kota Surakarta dengan 
Kabupaten Sukoharjo). Dampak langsung pelurusan ini adalah kemiringan sungai menjadi lebih besar sehingga kecepatan aliran sungai juga semakin besar. Perubahan bentuk sungai meander menjadi parabola juga semakin meningkatkan kecepatan aliran air karena tidak ada lagi hambatan atau pembelokan arus. Pembuatan tanggul disisi sungai menambah tingginya debit air yang dapat ditampung oleh Bengawan Solo. Kapasitas normal Bengawan Solo sebelum diluruskan adalah sebesar 200-300 m3/s, setelah diluruskan menjadi sebesar 700-900 m3/detik (BBWS Bengawan Solo, 2008). Dengan peningkatan kecepatan aliran tersebut dapat menyebabkan peningkataan debit, dan peningkatan debit dapat menyebabkan peningkatan daerah rawan banjir dan peningkatan risiko akibat banjir.

Pemodelan spasial dengan Sistem Informasi Geografis (SIG) dapat digunakan untuk memetakan daerah rawan genangan dan untuk menghitung risiko kerugian akibat luapan Bengawan Solo. Dengan pemodelan spasial ini akan dapat disimulasikan besaran debit dan daerah tergenang. Dengan mengetahui debit puncak pada saat banjir akan dapat digambarkan daerah yang tergenang. Pemodelan dalam hidrologi digunakan untuk menjelaskan proses perpindahan air dalam sistem aliran sungai berdasarkan variasi ruang dan waktu di dalam suatu Daerah Aliran Sungai (DAS) (Seyhan, 1977).

Salah satu perangkat lunak untuk pembuatan model analisis banjir adalah HEC-RAS yang dikembangkan oleh salah satu korps US Army Corps of Engineers (USACE) yaitu Hydrologic Engineering Center (HEC) yang dibentuk tahun 1964 sebagai institusi khusus di bidang teknik hidrologi yang kemudian dikenal sebagai HEC. HEC-RAS merupakan program yang didukung SIG dan dikembangkan untuk keperluan analisis hidrolika sungai, untuk aplikasi manajemen daerah dataran banjir, untuk studi evaluasi genangan banjir, dan untuk menilai perubahan profil aliran sungai. Dalam penelitian ini akan dilakukan simulasi model spasial untuk membandingkan model sebaran daerah genangan akibat banjir Bengawan Solo dengan menggunakan data debit puncak sebelum diluruskan dan setelah diluruskan. Dengan mengetahui perbandingan daerah tergenang akibat banjir Bengawan Solo pada kedua model tersebut maka dapat dihitung tingkat bahaya pada masing-masing model kemudian dianalisis pengaruh pelurusan Bengawan Solo ini terhadap tingkat bahaja dan tingkat risiko banjir di Kota Surakarta dan dapat dicari alternatif pemecahan masalahnya.

Dari latar belakang penelitian yang telah diuraikan diatas maka dapat disusun suatu rumusan masalah sebagai berikut: (1) bagaimana kemampuan teknologi SIG dan perangkat lunak hidrologi HEC-RAS dapat digunakan untuk memprediksi dan memetakan daerah daerah bahaya banjir?; dan (2) bagaimana menganalisis tingkat risiko banjir berdasarkan tingkat bahaya hasil pemodelan dan tingkat kerawanan banjir Bengawan Solo di penggal alur Bengawan Solo yang masuk wilayah Kota Surakarta?. Berangkat dari permasalahan tersebut maka penelitian ini mempunyai tujuan: (1) menerapkan pemodelan spasial dengan menggunakan Sistem Informasi Geografis dan program HEC-RAS, aplikasi pemodelan banjir, untuk memprediksi dan memetakan daerah bahaya banjir di Kota Surakaarta; dan (2) mengkaji dan memetakan tingkat risiko banjir di Kota Surakarta.

Secara teknis banjir merupakan debit sungai yang melebihi debit rata-rata pada sungai tersebut. Banjir secara sederhana dalam pandangan awam dapat diartikan sebagai aliran atau genangan yang menyebabkan kerugian bagi manusia. Banjir yang terjadi akibat meluapnya air dari saluran atau sungai disebut luapan, sedangkan banjir yang terjadi akibat tidak lancarnya aliran disebut genangan (Setiawan, 2008). Salah satu cara untuk mengetahui daerah yang rawan banjir adalah dengan identifikasi daerah banjir, yaitu dengan pemetaan daerah rawan genangan serta mengetahui besarnya debit banjir atau aliran permukaan yang berpotensi menyebabkan banjir. (Suwardi, 1999). Banjir yang dimaksud dalam penelitian ini adalah banjir Bengawan Solo yang diakibatkan oleh meluapnya aliran sungai Begawan Solo Hulu, bukan banjir luapan dari anak sungai Bengawan Solo.

Banjir yang biasa terjadi di Kota Surakarta dapat dibedakan menjadi dua, yaitu banjir kiriman dari Bengawan Solo hulu dan dari anak-anak sungai Bengawan Solo, serta banjir lokal yang terjadi akibat air hujan melebihi kapasitas drainase. Namun dari beberapa kali kejadian banjir di Kota Surakarta disebabkan oleh banjir kiriman bersamaan dengan banjir lokal. Hal ini terjadi karena pada saat Bengawan Solo induk tejadi banjir kiriman dari hulu maka air dari sistem drainase di Kota Surakarta tidak dapat mengalir ke Bengawan Solo induk sehingga menimbulkan genangan atau banjir lokal (Baiquni, 1988).

Pada penelitian ini analisis tingkat bahaya banjir di kota Surakarta dilakukan dengan cara pemodelan spasial. Penentuan tingkat bahaya banjir dalam penelitian ini dilakukan secara sistematik dalam beberapa tahapan, yaitu:

a. Membuat peta bahaya banjir Bengawan Solo di Kota Surakarta berdasarkan karakteristik banjir yaitu luas genangan dan kedalaman dengan menggunakan model HEC-RAS. Input HEC-RAS berupa data aliran diasumsikan dari debit puncak banjir sebelum pelurusan Bengawan Solo (sebelum 
tahun 1992) dan debit puncak banjir sesudah pelurusan (sesudah tahun 1993). Data geometrik sungai diturunkan dari data kontur peta Topografi Kota Suarakarta skala 1:10.000 dan hasil interpretasi foto udara skala 1:6000 serta diolah dengan menggunakan ekstensi HEC-GeoRAS pada ArcView 3.3. Hasil pemodelan ini yaitu peta bahaya banjir.

b. Menentukan dan membuat peta kerentanan terhadap banjir Bengawan Solo berdasarkan aspek fisik, sosial dan ekonomi dari elemen dalam risiko (element at risk) pada wilayah yang masuk bahaya banjir.

c. Menentukan dan membuat peta tingkat risiko banjir berdasarkan dengan tingkat bahaya yang ditentukan dan tingkat kerentanan yang telah diperoleh.

\section{METODE PENELITIAN}

Lokasi penelitian adalah sebagian kota Surakarta yang berpotensi terdampak banjir luapan Bengawan Solo induk. Untuk pemodelan spasial banjir dilakukan pada alur sungai Bengawan Solo induk dengan batas selatan yaitu perbatasan Kelurahan Semanggi Kecamatan Pasarkliwon dengan Kabupaten Sukoharjo, dan batas utara yaitu perbatasan Kelurahan Jebres Kecamatan Jebres dengan Kabupaten Karanganyar (Gambar 1).

Penelitian ini menggunakan metode survei dengan interpretasi foto udara dan citra satelit Quickbird dan menggunakan teknologi SIG untuk analisis data hasil interpretasi dan hasil pemodelan. Metode untuk analisis menggunakan metode analisis kuantitatif dan metode overlay untuk beberapa kajian tertentu. Kegiatan yang dilakukan pada tahap ini adalah: (1) pengumpulan data spasial Bengawan Solo yaitu peta dasar dan peta tematik; (2) pengumpulan data hidrologi meliputi data debit banjir Bangawan Solo sebelum dan sesudah pelurusan serta penampang melintang sungai; dan (3) pengumpulan data pendukung lain seperti data kependudukan, sosial dan ekonomi. Data yang telah dikumpulkan akan diolah dan dianalisis dengan pendekatan tertentu sehingga tujuan penelitian tercapai. Data ditampilkan dalam bentuk tabel, grafik, gambar, maupun peta.

\section{Analisis Karakteristik Banjir}

Analisis karakteristik banjir, terdiri atas beberapat kegiatan yaitu: (1) analisis debit/hidrograf rencana dengan menggunakan metode Gumbel untuk membandingkan debit puncak tahunan sebelum pelurusan dan setelah pelurusan; (2) analisis geometrik sungai dengan menggunakan ekstensi HEC-GeoRAS pada perangkat lunak ArcView; (3) analisis karateristik banjir yang terdiri atas luas, probalitias, dan kedalaman dengan menggunakan model HEC-RAS.

\section{Analisis Risiko Banjir}

Analisis risiko banjir, terdiri atas beberapat kegiatan yaitu: (1) analisis tingkat bahaya banjir pada model sebelum diluruskan (dengan input debit puncak sebelum pelurusan) dan pada model dengan input debit puncak setelah pelurusan di wilayah Kota Surakarta; (2) analisis tingkat kerentanan terhadap banjir dengan melakukan identifikasi elemen yang berisiko (element at risk) yang berada pada daerah bahaya banjir di Kota Surakarta; dan (3) analisis tingkat risiko banjir berdasarkan peta bahaya banjir dan peta tingkat kerentanan terhadap banjir di wilayah Kota Surakarta.

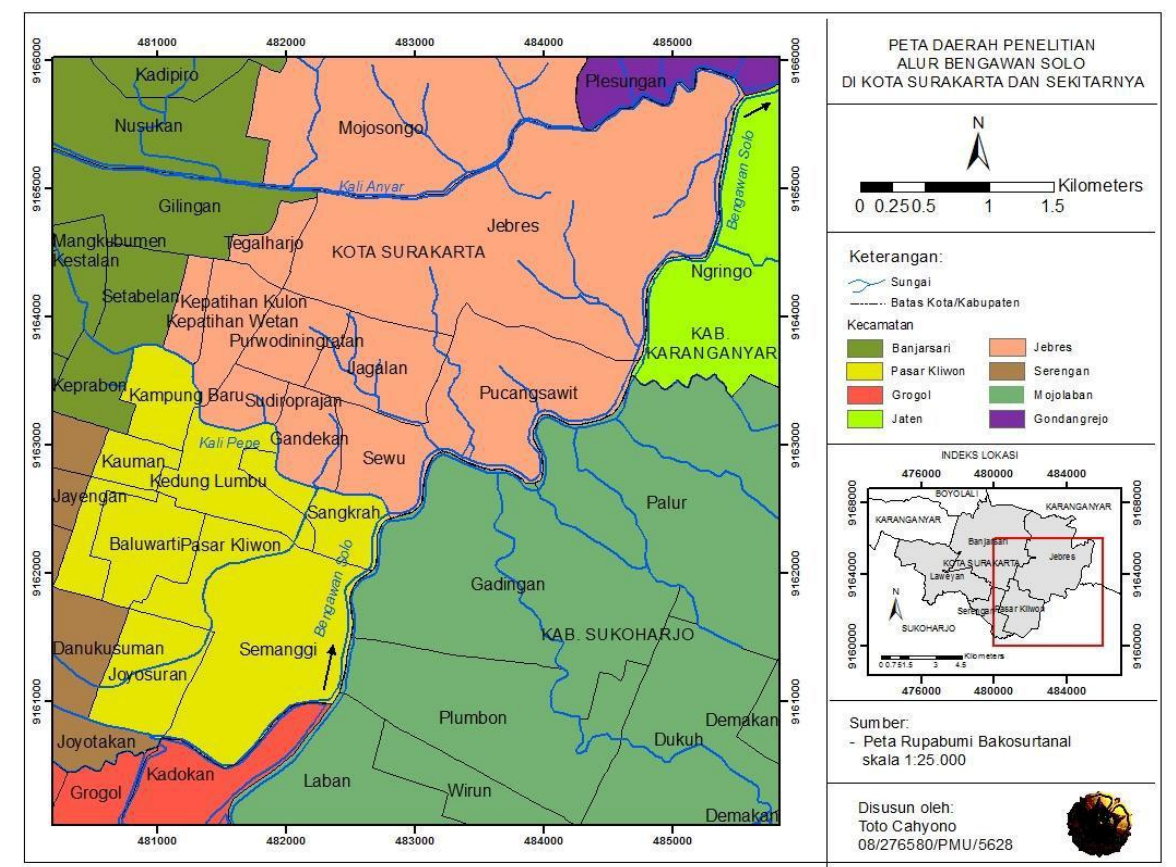

Gambar 1. Peta Derah Penelitian di Sebagian wilayah Kota Surakarta dan Sekitarnya 


\section{Analisis Hidrograf}

Dalam penelitian ini dilakukan analisis perbedaan debit maksimum banjir Bengawan Solo sebelum dan sesudah pelurusan. Data yang digunakan adalah data debit maksimum banjir tahunan dari tahun 1966 hingga tahun 2009 yang dikeluarkan oleh Balai Besar Wilayah Sungai (BBWS) Bengawan Solo. Debit maksimum tahunan Bengawan Solo ini menggambarkan debit harian terbesar setiap tahunnya di Bengawan Solo yang dicatat di pos pengamatan Jurug. Data tinggi muka air dinyatakan dalam meter dan dihitung dari dasar sungai. Dasar sungai Bengawan Solo di pos pengamatan Jurug berada pada ketinggian $79 \mathrm{~m}$ di atas permukaan laut. Data dikelompokkan menjadi dua, yaitu data sebelum pelurusan Bengawan Solo antara Tahun 1966 hingga Tahun 1992 dan data setelah pelurusan Bengawan Solo yaitu dari Tahun 1993 hingga Tahun 2009 (Gambar 2).

Dari data tinggi muka air (TMA) dan debit maksimum tahunan dapat diketahui rata-rata debit maksimum tahunan Bengawan Solo sebelum pelurusan (tahun 1966 - 1992) adalah sebesar 779,89 m3/s dengan ketinggian muka air adalah sebesar 7,05 $\mathrm{m}$ dari dasar sungai. Sedangkan setelah pelurusan (tahun 1993-2008) diketahui rata-rata debit maksimum tahunan Bengawan Solo adalah sebesar $910 \mathrm{m3} / \mathrm{s}$ dan ketinggian muka air adalah 7,55 $\mathrm{m}$ dari dasar sungai. Dari data tersebut diketahui telah terjadi kenaikan rata-rata debit maksimum tahunan dari $779,89 \mathrm{~m} 3 / \mathrm{s}$ menjadi $910,0 \mathrm{~m} 3 / \mathrm{s}$ atau meningkat sebesar $17 \%$.

Meskipun secara nyata angka rata-rata debit mengalami kenaikan, namun untuk validasi besaran kenaikan debit tersebut maka akan dilakukan uji statistik dengan metode T-Test berpasangan. Karena jumlah populasi data yang berbeda (27 data dan 17 data) maka data yang diuji diambil 17 data. Data debit maksimum sebelum dan sesudah pelurusan dilakukan pengurutan (rangking) dari yang terbesar hingga yang terkecil. Data debit sebelum pelurusan diambil 17 data dengan nilai terbesar dan data debit setelah pelurusan diambil seluruhnya 17 data.

Dari hasil uji T-Test diketahui nilai rata-rata debit maksimum tahunan sebelum pelurusan adalah 923,29 (m3/s) dengan standard deviasi 320,47, sedangkan nilai rata-rata debit maksimum tahunan sesudah pelurusan adalah 978 (m3/s) dengan standard deviasi 347,96. Dari data tersebut memang sepertinya terjadi kenaikan debit yang cukup besar akibat pelurusan. Namum demikian angka ini masih perlu di uji statistik lebih lanjut.

Dari hasil uji statistik T-tets diketahui bahwa nilai $\mathrm{t}=1.626<\mathrm{t}$ table $=2.110$ artinya Ho diterima atau variabel dinyatakan tidak berpengaruh, dan nilai signifikansi $=0.123>a=0.05$ artinya variabel tidak berpengaruh nyata, maka dapat disimpulkan bahwa secara statistik debit puncak tahunan Bengawan Solo sebelum dan sesudah pelurusan tidak berbeda nyata, artinya debit puncak setelah pelurusan dan sebelum pelurusan tidak terjadi perbedaan yang signifikan. Dengan kata lain bahwa kegiatan pelurusan alur Bengawan Solo tidak mengakibatkan perubahan yang signifikan terhadap debit maksimum banjir tahunan. Dengan demikian besaran debit maksimum tahunan tidak ditentukan oleh bentuk alur meander atau lurus, akan tetapi ditentukan oleh faktor lain. Faktor yang kemungkinan berpengaruh terhadap debit adalah curah hujan dan perubahan penggunaan lahan di hulu, namun faktor pengaruh tersebut tidak dibahas dalam penelitian ini.

Analisis debit maksimum rancangan ini digunakan sebagai bahan masukan di dalam pemodelan dengan HEC-RAS. Penghitungan debit maksimum rancangan dilakukan berdasarkan data debit maksimum sebelum pelurusan (tahun 1966-1992) dan data debit maksimum sesudah pelurusan (1993-2009). Debit rancangan ini dihitung untuk periode ulang banjir lima, 10, 20, 40, 60, 80 dan 100 tahun. Analisis untuk menghitung debit maksimum tahunan Bengawan Solo menggunakan metode Gumbel.

Hasil perhitungan debit maksimum rancangan berdasarkan data debit sebelum pelurusan disajikan dalam Tabel 1. Dari data debit maksimum rancangan pada Tabel 1 tersebut maka yang akan digunakan sebagai input untuk pemodelan adalah debit rancangan untuk periode ulang 10, 20, 40 dan 60 tahun. Alasan dipilih periode ulang terendah 10 tahun karena debit periode ulang kurang dari 10 tahun masih dibawah kapasitas maksimum Bengawan Solo. Sedangkan alasan dipilih periode ulang maksimum 60 tahun adalah untuk mengantispasi luapan banjir Bengawan Solo yang ekstrim, hal ini diperlukan untuk perencanaan pembangunan yang lebih baik. 


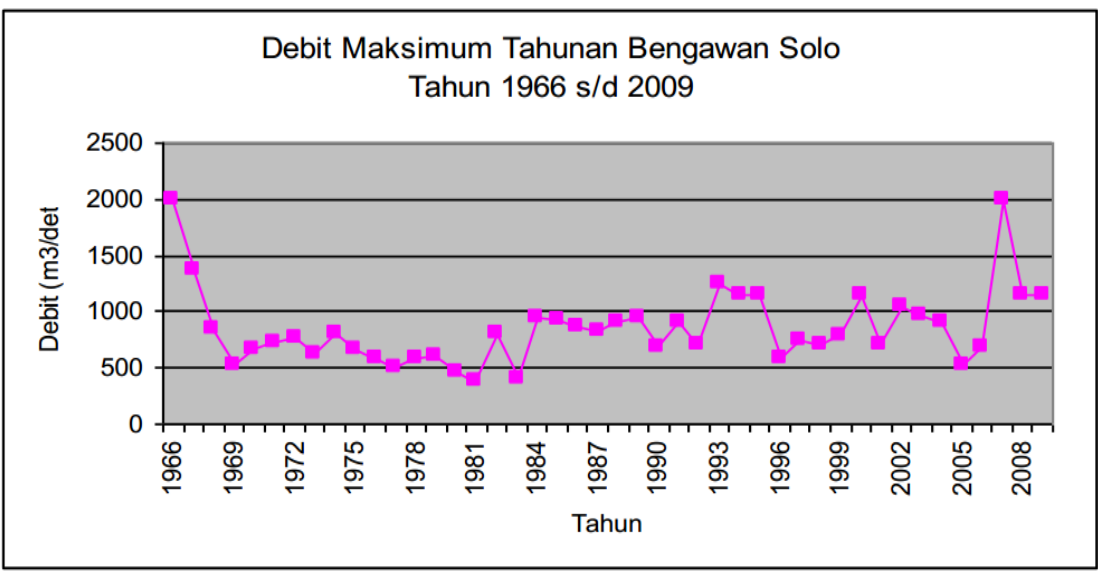

Gambar 2. Grafik Debit Maksimum Tahunan Bengawan Solo Tahun 1966-2009

Tabel 1. Debit maksimum rancangan berdasarkan data sebelum pelurusan

\begin{tabular}{cccc}
\hline $\begin{array}{c}\text { Periode Ulang } \\
\text { (tahun) }\end{array}$ & $\begin{array}{c}\text { LP } \\
\text { (Peluang) }\end{array}$ & Y = -LN(-LN(LP)) & $\begin{array}{c}\text { Debit Puncak Rancangan (Q) } \\
\left(\mathrm{m}^{3} / \mathrm{s}\right)\end{array}$ \\
\hline 5 & 0.800 & 1.499 .940 & 1088.23 \\
10 & 0.900 & 2.250 .367 & 1322.74 \\
20 & 0.950 & 2.970 .195 & 1547.69 \\
40 & 0.975 & 3.676 .247 & 1768.33 \\
60 & 0.983 & 4.085 .953 & 1896.36 \\
80 & 0.988 & 4.375 .744 & 1986.92 \\
100 & 0.990 & 4.600 .149 & 2057.05 \\
\hline
\end{tabular}

Sumber : Hasil Analisis

Analog dengan metode penghitungan debit maksimum rancangan berdasarkan data debit maksimum sebelum pelurusan maka hasil analisis data debit maksimum rancangan berdasarkan data debit sesudah pelurusan disajikan pada Tabel 2. Dari analisis Tabel 2 diketahui bahwa berdasarkan perhitungan debit rancangan maksimum banjir berdasarkan data sesudah pelurusan maka periode ulang debit maksimum mengalami percepatan. Sebagai contoh debit rancangan sebelum pelurusan untuk periode ulang 100 tahun sebesar $2057 \mathrm{~m}^{3} / \mathrm{s}$, bisa dipercepat menjadi 60 tahun sebesar $2004 \mathrm{~m}^{3} / \mathrm{s}$ berdasarkan data sesudah pelurusan. Namum demikian percepatan ini bukan akibat dari pelurusan alur

Analisis tinggi muka air (TMA) maksimum ini analog seperti pada analisis debit rancangan maksimum. Data TMA diperoleh dari Tahun 1966 hingga 2009, data kemudian diurutkan berdasarkan nilai debit puncak terkecil hingga debit puncak terbesar dari tahun 1966 hingga 2009. Hasil perhitungan masih dalam satuan meter di atas dasar sungai. Untuk mengetahui ketinggian muka air di atas permukaan laut maka nilainya ditambah dengan tinggi elevasi dasar sungai Bengawan Solo di pos pengamatan Jurug, yaitu setinggi $79 \mathrm{~m}$ dpal (Tabel 3).

TMA rancangan untuk data debit maksimum rancangan sesudah pelurusan dihitung dengan cara yang sama untuk TMA sebelum pelurusan. Hasil perhitungan TMA rancangan berdasarkan data sesudah pelurusan disajikan pada Tabel 4 .

\section{Pembuatan DEM}

Untuk melakukan pemodelan banjir maka data spasial yang perlu dipersiapkan sebagai data dasar adalah peta DEM. Dalam penelitian ini pembuatan DEM berdasarkan garis kontur dari peta topografi skala 1:10.000 yang dibuat oleh Dinas Pekerjaan Umum Kotamadya Surakarta Tahun 1991 dengan interval kontur 2 meter dan ditambahkan data titik tinggi dari penentuan beda tinggi terutama daerah sekitar sisi kanan kiri Bengawan Solo dengan cara menghitung beda paralaks pada foto udara. Seluruh titik yang dihitung beda tingginya sebanyak 370 titik. Titik yang dipakai sebagai referensi ketinggian adalah titik tinggi peta Rupabumi Bakosurtanal dan titik titik muka air sungai yang relatif dianggap datar.

Hasil penggambaran garis kontur dari Peta Topografi dan dari hasil interpolasi titik tinggi dapat dilihat pada Gambar 3. Pembuatan garis kontur tidak hanya pada wilayah Kota Surakarta, tetapi juga di sisi kanan Bengawa Solo yang masuk ke wilayah Kabupaten Sukoharjo dan Karanganyar. Hal ini disebabkan luapan banjir Bengawan Solo melimpah ke sisi kanan kiri sungai sesuai kondisi topografinya. Dari peta kontur tersebut kemudian disajikan dalam tampilan DEM_TIN dengan menggunakan perangkat lunak ArvView dengan ekstensi 3D Analyst (Gambar 4). 
Tabel 2. Debit Maksimum Rancangan Berdasarkan Data Sesudah Pelurusan

\begin{tabular}{cccc}
\hline $\begin{array}{c}\text { Periode Ulang } \\
\text { (tahun) }\end{array}$ & $\begin{array}{c}\text { LP } \\
(\text { Peluang })\end{array}$ & Y = -LN(-LN(LP)) & $\begin{array}{c}\text { Debit Puncak Rancangan }(\mathrm{Q}) \\
\left(\mathrm{m}^{3} / \mathrm{s}\right)\end{array}$ \\
\hline 5 & 0.800 & 1.499 .940 & 1196.39 \\
10 & 0.900 & 2.250 .367 & 1430.90 \\
20 & 0.950 & 2.970 .195 & 1655.84 \\
40 & 0.975 & 3.676 .247 & 1876.48 \\
60 & 0.983 & 4.085 .953 & 2004.52 \\
80 & 0.988 & 4.375 .744 & 2095.08 \\
100 & 0.990 & 4.600 .149 & 2165.20 \\
\hline
\end{tabular}

Sumber : Hasil Analisis

Tabel 3. Debit Maksimum Rancangan dan Tinggi Muka Air Rancangan Berdasarkan Data Sebelum Pelurusan

\begin{tabular}{cccc}
\hline $\begin{array}{c}\text { Periode Ulang } \\
\text { (tahun) }\end{array}$ & $\begin{array}{c}\text { Debit Rancangan Sebelum } \\
\text { Pelurusan }(\mathrm{X})\end{array}$ & $\begin{array}{c}\text { TMA } \\
\left(\mathrm{Y}=\left(0.0036^{\star} \mathrm{X}\right)+4.3999\right) \mathrm{m}\end{array}$ & $\begin{array}{c}\text { Ketinggian Elevasi } \\
(\mathrm{TMA}+79) \mathrm{m} \text { dpal }\end{array}$ \\
\hline 5 & 1088 & 8.3 & 87.3 \\
10 & 1323 & 9.2 & 88.2 \\
20 & 1548 & 10.0 & 89.0 \\
40 & 1768 & 10.8 & 89.8 \\
60 & 1896 & 11.2 & 90.2 \\
80 & 1987 & 11.6 & 90.6 \\
100 & 2057 & 11.8 & 90.8 \\
\hline
\end{tabular}

Sumber : Hasil Analisis

Tabel 4. Debit Maksimum Rancangan dan Tinggi Muka Air Rancangan Berdasarkan Data Sesudah Pelurusan

\begin{tabular}{cccc}
\hline $\begin{array}{c}\text { Periode Ulang } \\
\text { (tahun) }\end{array}$ & $\begin{array}{c}\text { Debit Rancangan Sebelum } \\
\text { Pelurusan }(\mathrm{X})\end{array}$ & $\begin{array}{c}\text { TMA } \\
\left(\mathrm{Y}=\left(0.0036^{*} \mathrm{X}\right)+4.3999\right) \mathrm{m}\end{array}$ & $\begin{array}{c}\text { Ketinggian Elevasi } \\
(\mathrm{TMA}+79) \mathrm{m} \mathrm{dpal}\end{array}$ \\
\hline 5 & 1196 & 8.7 & 87.7 \\
10 & 1431 & 9.6 & 88.6 \\
20 & 1656 & 10.4 & 89.4 \\
40 & 1876 & 11.2 & 90.2 \\
60 & 2005 & 11.6 & 90.6 \\
80 & 2095 & 11.9 & 90.9 \\
100 & 2165 & 12.2 & 91.2 \\
\hline
\end{tabular}

Sumber : Hasil Analisis

\section{Pembuatan Peta Bahaya}

Untuk membuat peta model bahaya banjir pada penelitian ini dilakukan dengan menggunakan perangkat lunak ArcView dengan ekstensi HEC-GeoRAS dan perangkat lunak HEC-RAS. Ekstensi HEC-GeoRAS berfungsi untuk pemrosesan data geospasial yang akan digunakan sebagai bahan input data geometrik HEC-RAS dan data pelengkap lainnya. Data geometrik yang dibangun oleh HEC-GeoRAS meliputi sungai, penggal sungai, penampang melintang, tebing sungai, jarak antar penampang melintang serta kekasaran saluran dan permukaan yang dinyatakan dengan nilai koefisien Manning (n).

Data hidrologi yang dipakai sebagai input dalam pemodelan ini adalah data debit maksimum rancangan berdasarkan hasil analisis data debit sebelum dan sesudah pelurusan alur Bengawan Solo, yang secara ringkas ditampilkan dalam Tabel 5 berikut. Alasan mengapa dipilih periode ulang 10, 20, 40, dan 60 tahun sebagai input dalam pemodelan ini dikarenakan berdasarkan hasil analisis debit rancangan maka debit yang nilainya diatas debit normal adalah setelah periode ulang 10 tahun. Dengan demikian untuk periode ulang lima tahun tidak dimodelkan karena masih dibawah kapasitas maksimum alur Bengawan Solo. Data debit banjir maksimum Bengawan Solo yang tercatat adalah sekitar $2000 \mathrm{~m} 3 / \mathrm{s}$ yang berdasarkan hasil perhitungan itu akan terulang dengan periode 60 tahun. Dengan demikian maka yang digunakan sebagai input pemodelan ini maksimum digunakan periode ulang 60 tahun. Untuk kepentingan pembuatan peta risiko banjir maka pada peta bahaya banjir ini juga akan dilakukan pemberian bobot (scoring) seperti disajikan pada Tabel 6 dan Gambar 5. 


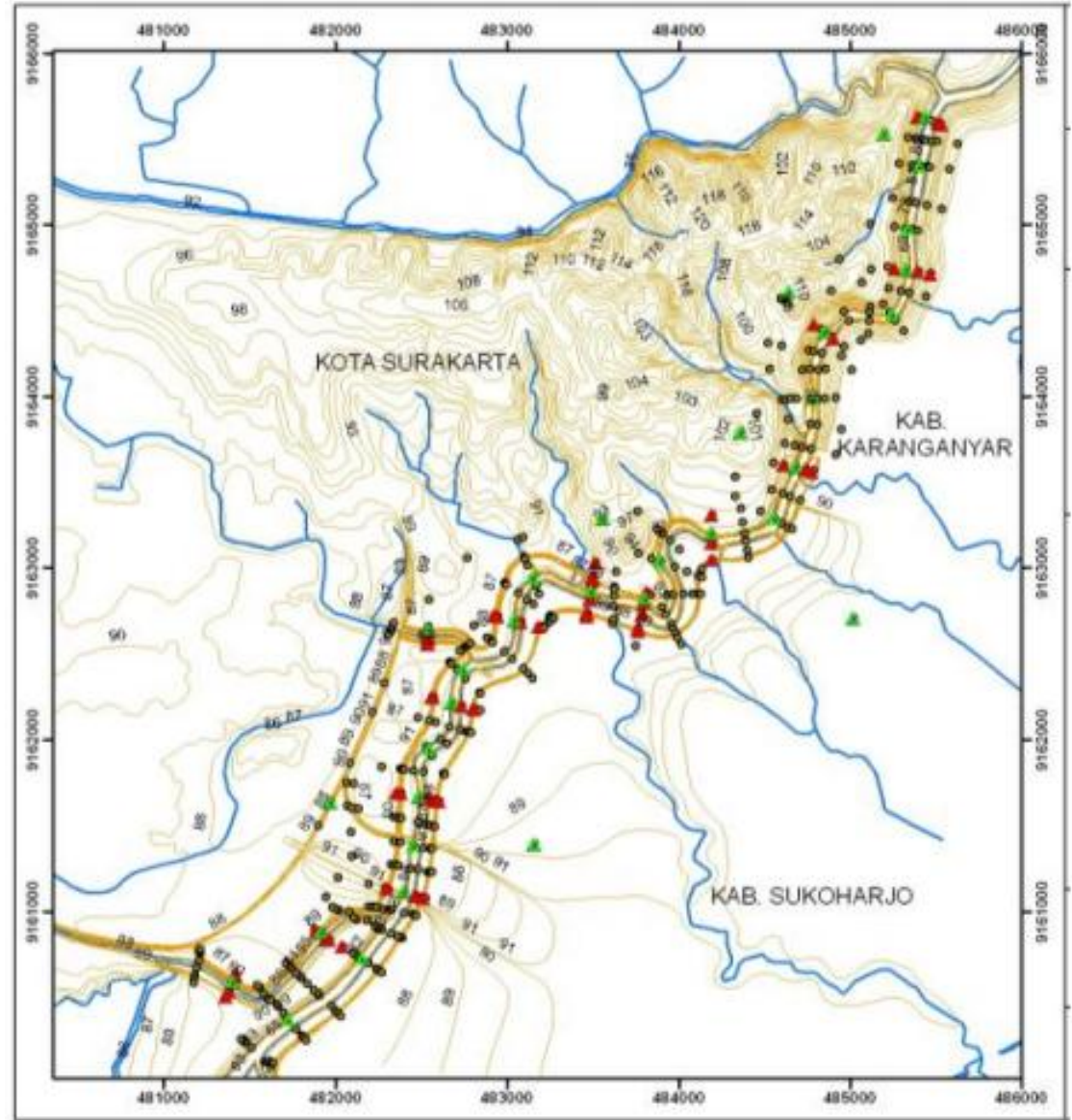

Gambar 3. Peta Kontur Hasil Interpolasi

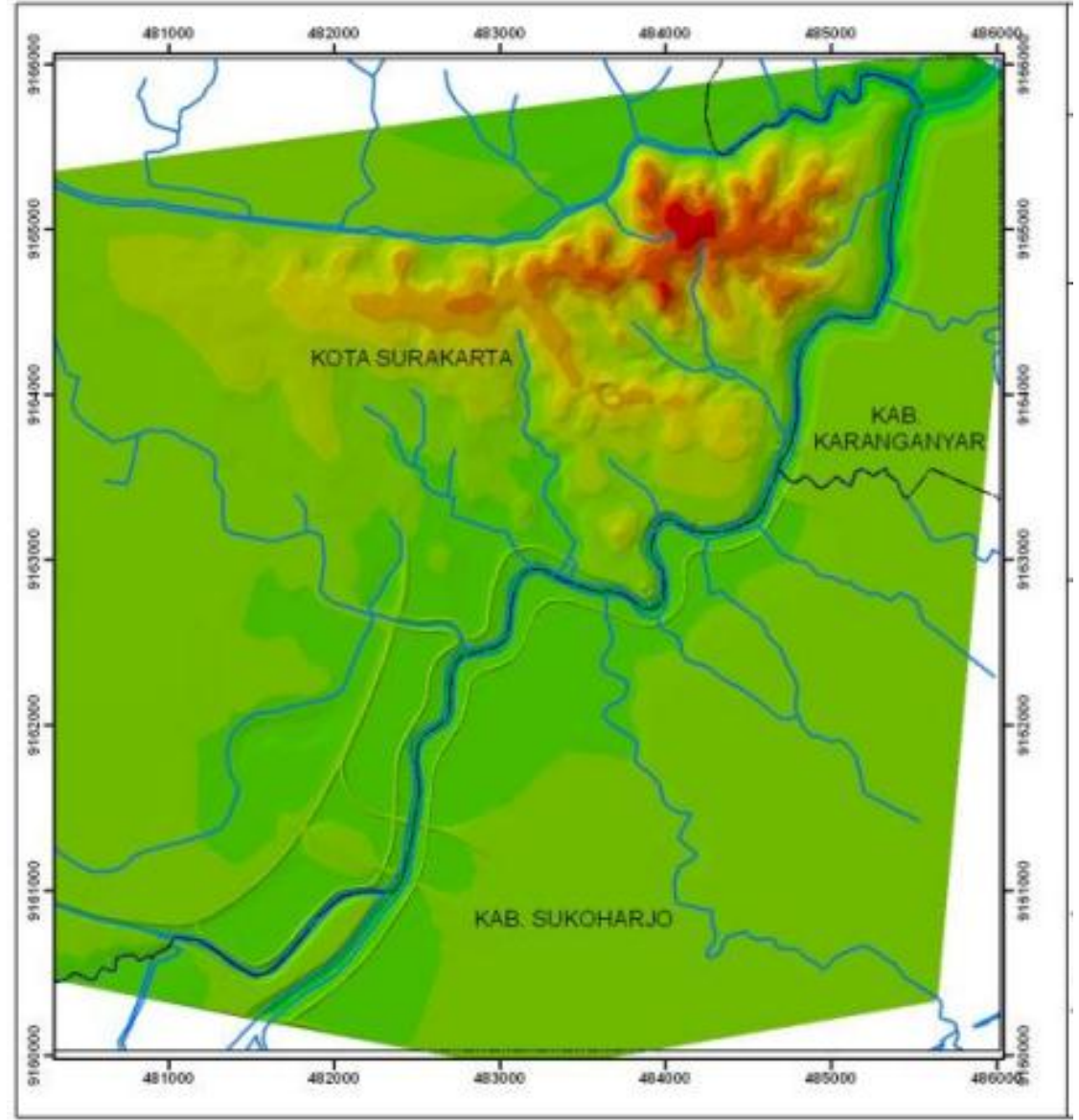

Gambar 4. Peta DEM Daerah Penelitian 
Tabel 5. Data Debit Maksimum Rancangan untuk Input Pemodelan

\begin{tabular}{ccc}
\hline $\begin{array}{c}\text { Periode } \\
\text { Ulang } \\
\text { tahun) }\end{array}$ & $\begin{array}{c}\text { Debit Rancangan } \\
\text { Sebelum } \\
\text { Pelurusan }(\mathrm{m} 3 / \mathrm{s})\end{array}$ & $\begin{array}{c}\text { Debit Rancangan } \\
\text { Sesudah } \\
\text { Pelurusan }(\mathrm{m} 3 / \mathrm{s})\end{array}$ \\
\hline 10 & 1323 & 1431 \\
20 & 1548 & 1656 \\
40 & 1768 & 1876 \\
60 & 1896 & 2005 \\
\hline
\end{tabular}

Sumber : Hasil Analisis

Tabel 6. Klasifikasi Peta Bahaya Banjir

\begin{tabular}{cclc}
\hline \multicolumn{2}{c}{$\begin{array}{c}\text { Kedalaman } \\
\text { Genangan }(\mathrm{m})\end{array}$} & Kelas Bahaya & $\begin{array}{c}\text { Bobot } \\
(\text { score })\end{array}$ \\
\hline \multicolumn{2}{c}{ Tidak tergenang } & Tidak bahaya & 0 \\
0 & $-0,5$ & Bahaya Ringan & 1 \\
0,501 & -1 & Agak bahaya & 2 \\
1,001 & $-1,5$ & Bahaya Sedang & 3 \\
1,501 & -2 & Bahaya & 4 \\
& $>2,0$ & Sangat Bahaya & 5 \\
\hline
\end{tabular}

Sumber: Woods (2007) dengan modifikasi

\section{Pembuatan Peta Kerentanan}

Peta kerentanan dalam penelitian ini diturunkan dari layer penggunaan lahan Peta Rupabumi Indonesia skala 1:25000 dan diperbaharui dengan menggunakan citra QuickBird tahun 2006. Dalam penyusunan peta kerentanan banjir ini menggunakan metode seperti yang dilakukan oleh (Kushartati, 2006). Penentuan tingkat kerentanan dilakukan dengan pendekatan skoring. Parameter yang dianggap mempunyai potensi kerusakan dan kerugian yang besar dinilai dengan skor tinggi, begitu juga sebaliknya. Kondisi kerentanan yang digunakan adalah dari aspek penduduk yaitu kepadatan penduduk yang mempresentasikan kerugian korban jiwa, serta penggunaan lahan, infrastruktur, dan kegiatan ekonomi yang mempresentasikan kerugian ekonomi, sosial dan budaya. Parameter penggunaan lahan secara garis besar dibagi tiga kelompok, yaitu penggunaan lahan permukiman, lahan budidaya seperti sawah, kebun maupun tegalan dengan produktivitasnya, serta penggunaan lahan non permukiman dan non budidaya. Untuk lebih jelasnya klasifikasi dan parameter untuk menyusun peta kerentanan disajikan pada Tabel 7 dan Gambar 6.

\section{Pembuatan Peta Risiko}

Dalam penelitian ini tidak sampai pada tahap penilaian terhadap kerusakan atau kehilangan harta benda atau properti lainnya, namun hanya sampai pada penghitungan kelas risiko yang didasarkan pada hasil perkalian nilai bahaya (Tabel 6) dengan nilai kerentanan (Tabel 7). Penghitungan dengan sistem skoring ini untuk mempermudah dalam klasifikasi kelas risiko. Hasil klasifikasi risiko disajikan pada Tabel 8, dan peta Kelas Risiko disajikan pada Gambar 7.

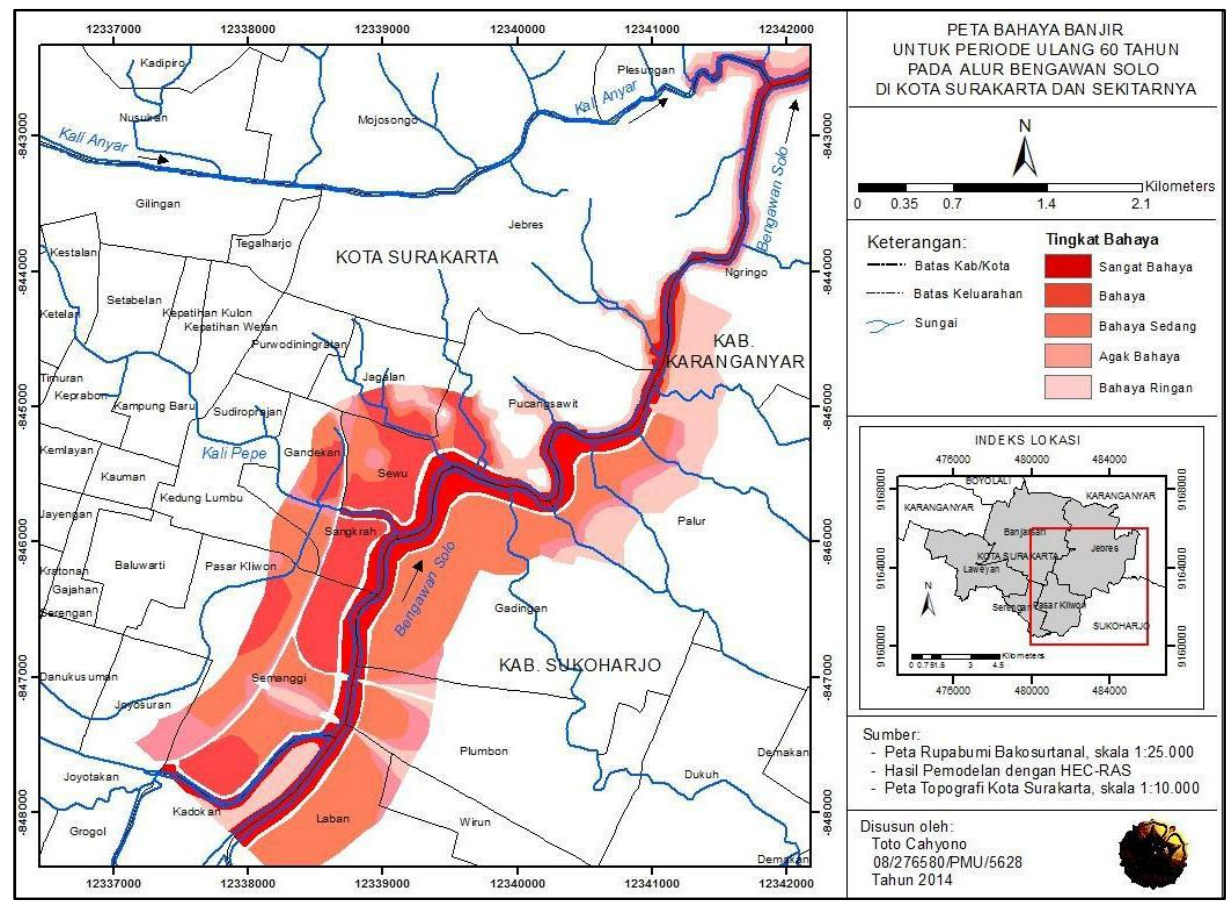

Gambar 5. Peta Tingkat Bahaya Banjir Daerah Penelitian 
Tabel 7. Parameter dan Klasifikasi Peta Kerentanan

\begin{tabular}{|c|c|c|c|}
\hline Aspek Parameter & Jenis Penggunaan Lahan & Kelas Kerentanan & Bobot (score) \\
\hline Penduduk & Permukiman & Sangat Rentan & 4 \\
\hline \multirow[t]{5}{*}{ Sosial-Ekonomi } & Perkantoran & Rentan & 3 \\
\hline & Pendidikan & Rentan & 3 \\
\hline & Perbelanjaan & Rentan & 3 \\
\hline & Pelayanan & Rentan & 3 \\
\hline & Industri & Rentan & 3 \\
\hline \multirow[t]{7}{*}{ Produktivitas Lahan } & Sawah Irigasi & Agak Rentan & 2 \\
\hline & Perkebunan & Agak Rentan & 2 \\
\hline & Tegalan & Kurang Rentan & 1 \\
\hline & Kebun & Kurang Rentan & 1 \\
\hline & Semak Belukar & Tidak Rentan & 0 \\
\hline & Rumput & Tidak Rentan & 0 \\
\hline & Tubuh Air & Tidak Rentan & 0 \\
\hline
\end{tabular}

Sumber: Kushartati (2006) dengan modifikasi

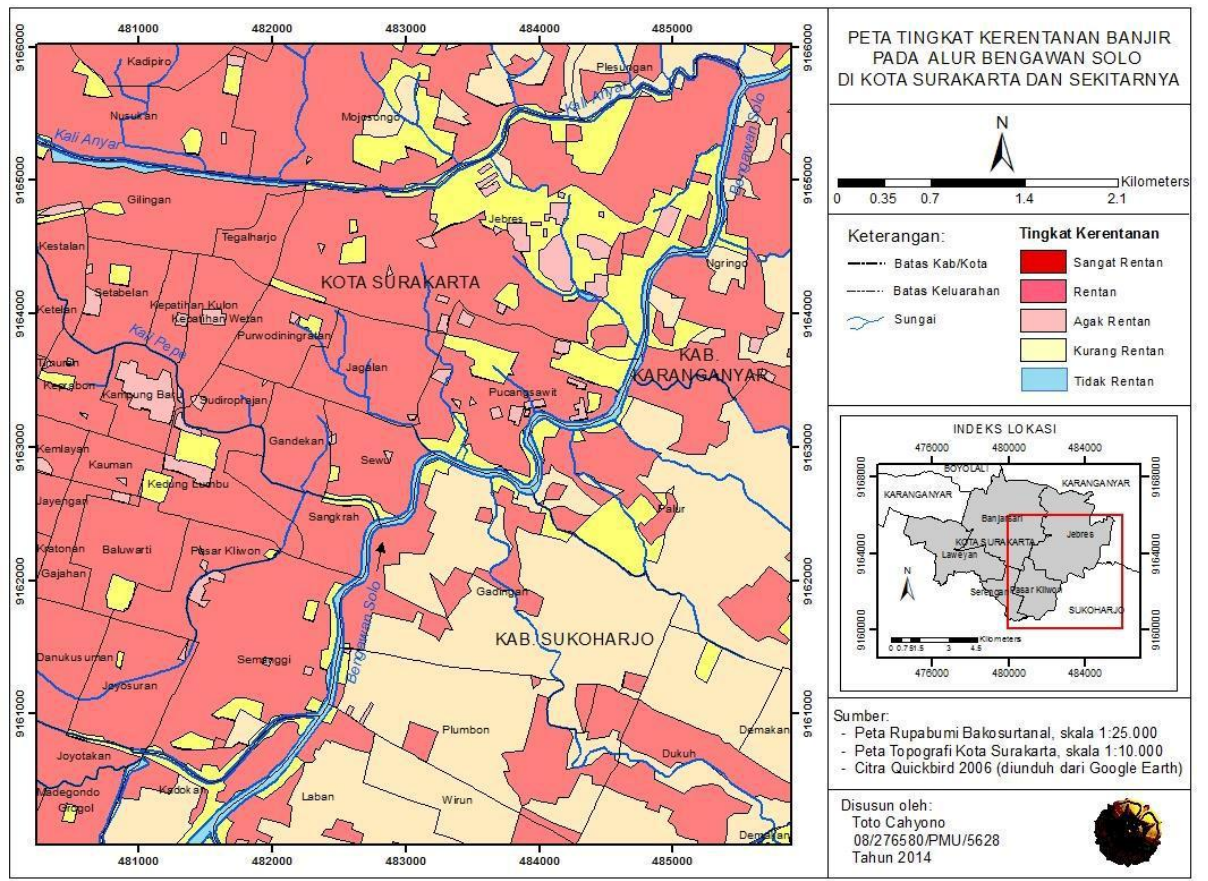

Gambar 6. Peta Tingkat Kerentanan Banjir Daerah Penelitian

Tabel 8. Klasifikasi Nilai Risiko Banjir Daerah Penelitian

\begin{tabular}{|c|c|c|c|c|c|c|}
\hline \multirow{2}{*}{\multicolumn{2}{|c|}{$\begin{array}{c}\text { NILAI RISIKO } \\
\text { Kelas Bahaya }\end{array}$}} & \multicolumn{5}{|c|}{ Kelas Kerentanan } \\
\hline & & \multirow{2}{*}{$\begin{array}{c}\text { Sangat Rentan } \\
4 \\
\end{array}$} & \multirow{2}{*}{$\begin{array}{c}\text { Rentan } \\
3\end{array}$} & \multirow{2}{*}{$\begin{array}{c}\text { Agak Rentan } \\
2\end{array}$} & \multirow{2}{*}{$\begin{array}{c}\text { Kurang Rentan } \\
1 \\
\end{array}$} & \multirow{2}{*}{$\begin{array}{c}\text { Tidak Rentan } \\
0 \\
\end{array}$} \\
\hline Kelas & Nilai & & & & & \\
\hline Sangat Bahaya & 5 & 20 & 15 & 10 & 5 & 0 \\
\hline Bahaya & 4 & 16 & 12 & 8 & 4 & 0 \\
\hline Bahaya Sedang & 3 & 12 & 9 & 6 & 3 & 0 \\
\hline Agak Bahaya & 2 & 8 & 6 & 4 & 2 & 0 \\
\hline Bahaya Ringan & 1 & 4 & 3 & 2 & 1 & 0 \\
\hline Tidak Bahaya & 0 & 0 & 0 & 0 & 0 & 0 \\
\hline
\end{tabular}

Sumber : Hasil Analisis 


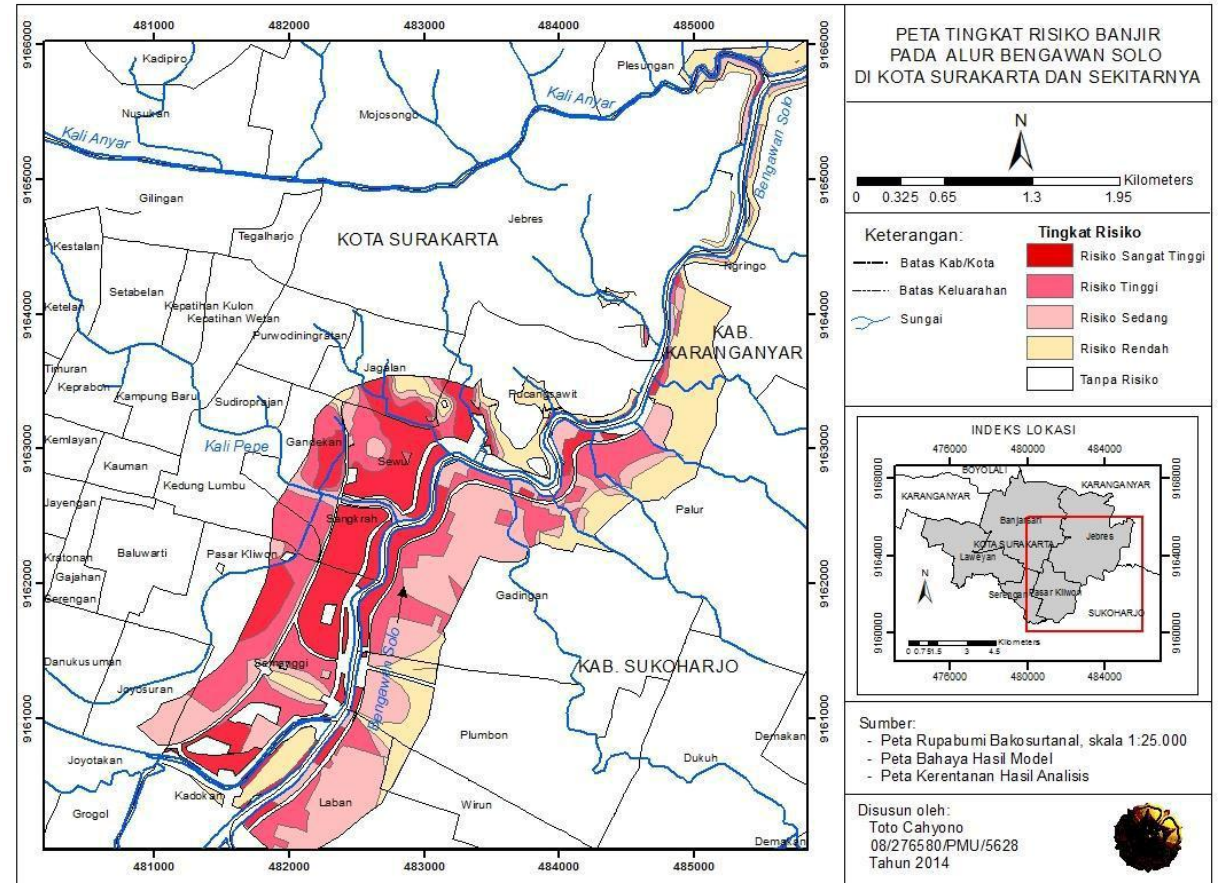

Gambar 7. Peta Tingkat Risiko Banjir Daerah Penelitian

\section{HASIL DAN PEMBAHASAN}

\section{Peta Bahaya, Kerentanan, dan Risiko}

Hasil pemodelan ini adalah berupa peta genangan hasil pemodelan yang selanjutnya disebut peta rawan atau peta bahaya banjir untuk periode ulang 10, 20, 40, dan 60 tahun (Gambar 8). Dari uraian pembahasan peta hasil pemodelan banjir yang telah dilakukan, maka dipilih satu peta model bahaya banjir yang paling besar debit dan luasan genangannya untuk kemudian dijadikan dasar dalam penyusunan peta bahaya banjir Kota Surakarta, yaitu peta genangan hasil pemodelan berdasarkan data sesudah pelurusan untuk periode ulang 60 tahun. Model ini dipilih karena input debit yang digunakan dalam pemodelan nilainya sama dengan debit puncak banjir Bengawan Solo yang pernah terjadi pada tahun 1966 dan tahun 2007 yaitu sekitar $2000 \mathrm{~m} 3 /$ det. Untuk menyusun peta bahaya banjir dalam penelitian ini, maka dilakukan klasifikasi ulang untuk kedalaman genangan, dimana Peta Bahaya Banjir yang disusun akan dikelompokkan menjadi lima kelas, seperti disajikan pada Gambar 9.

Dari pembahasan hasil perhitungan hidrologi telah diketahui bahwa pelurusan alur Bengawan Solo tidak berdampak langsung pada bahaya dan risiko banjir di Kota Surakarta. Pelurusan alur yang dilakukan pada penggal Bengawan Solo di daerah Kabupaten Sukoharjo (antara perbatasan Sukoharjo-Wonogiri sampai perbatasan Sukoharjo-Surakara) memang berpengaruh terhadap kecepatan aliran, namun kurang berpengaruh terhadap debit. Perubahan debit puncak tahunan lebih disebabkan oleh perubahan penggunaan lahan di daerah hulu, namun permasalahan ini tidak dibahas dalam penelitian ini.

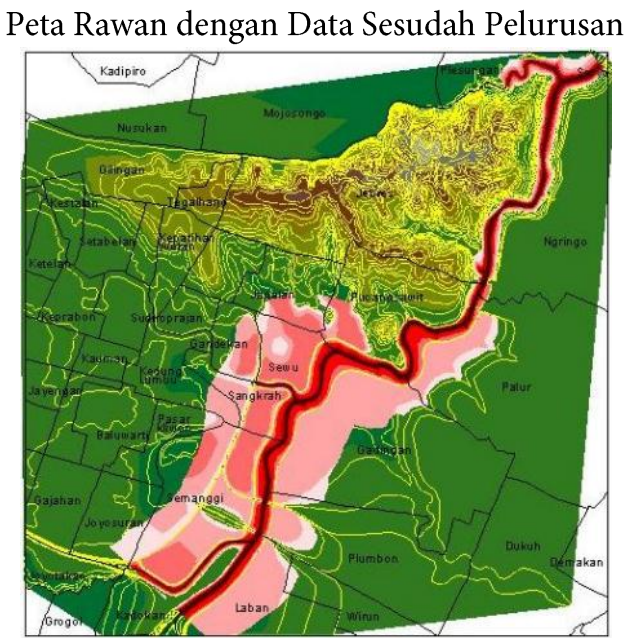

\section{Peta Rawan dengan Data Sebelum Pelurusan}

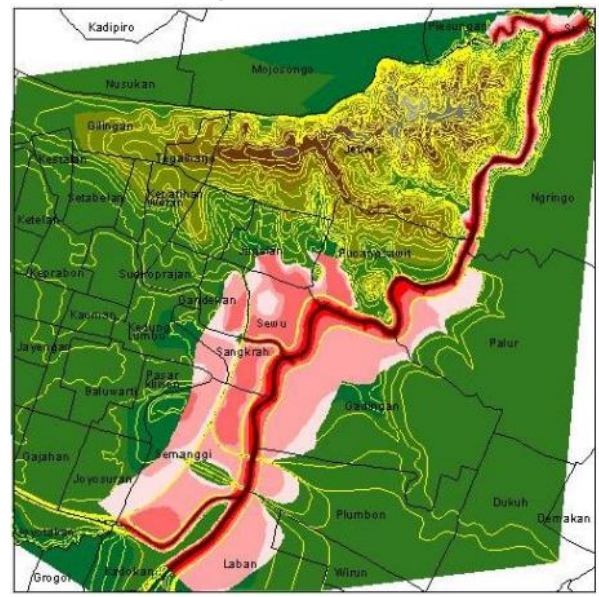

Periode Ulang 10 tahun

Gambar 8. Peta Hasil Pemodelan 
Lanjutan Gambar 8...

Peta Rawan dengan Data Sebelum Pelurusan

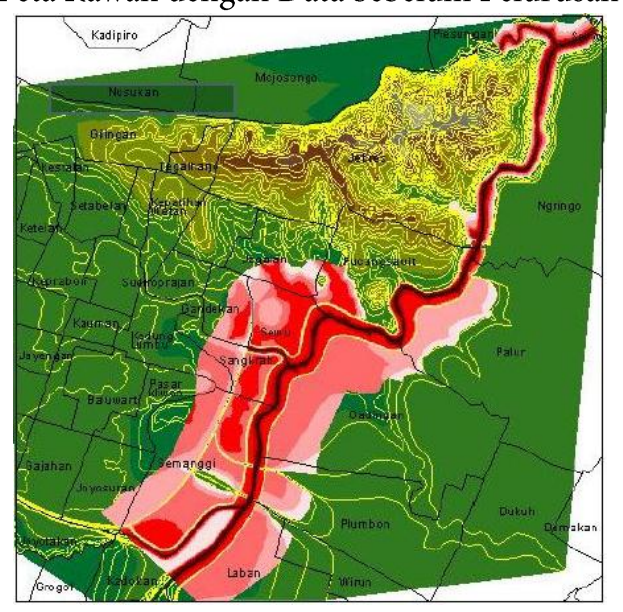

Peta Rawan dengan Data Sesudah Pelurusan

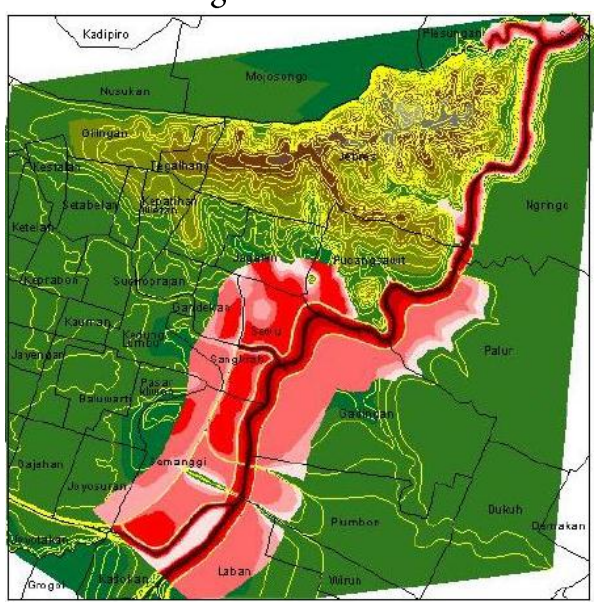

Periode Ulang 20 Tahun
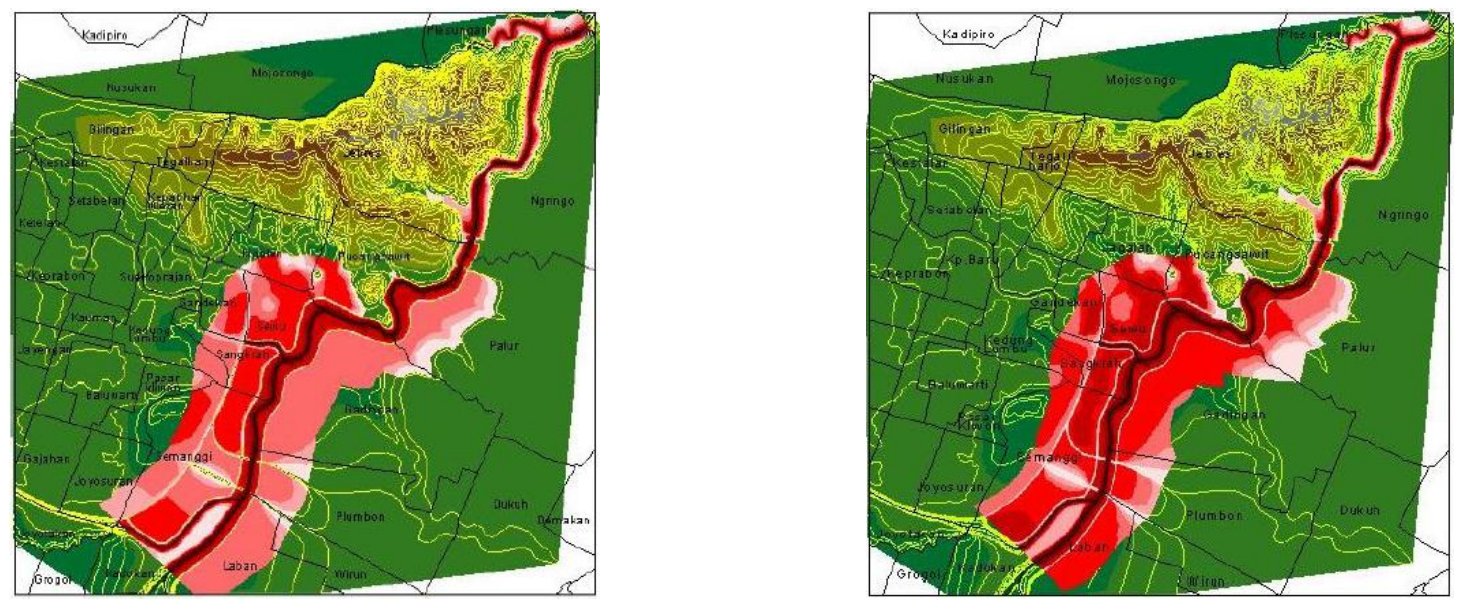

Periode Ulang 40 Tahun
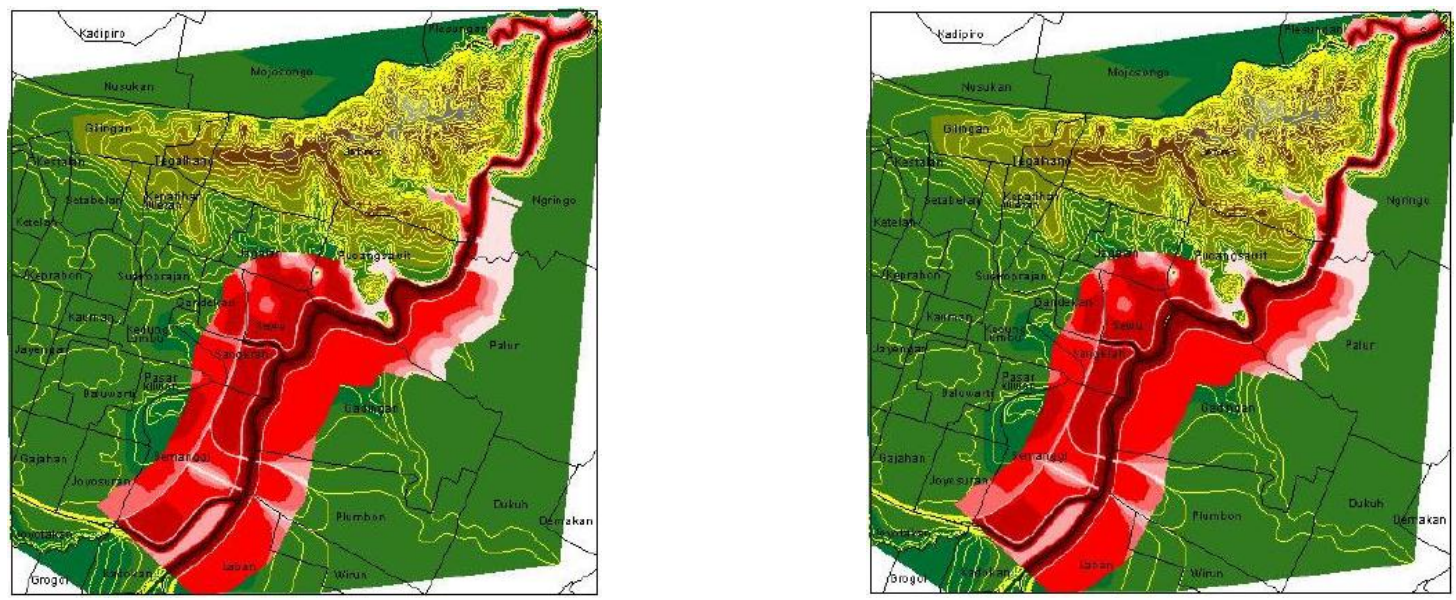

Periode Ulang 60 Tahun

Gambar 8. Peta Hasil Pemodelan

Dengan adanya tanggul sungai di sisi kanan kiri Bengawan Solo sebenarnya sangat bermanfaat untuk menanggulangi luapan banjir Bengawan Solo. Kasus banjir pada akhir tahun 2007 yang meluas di wilayah Kota Surakarta lebih disebabkan adanya beberapa titik tanggul yang jebol atau tergerus sehingga air meluap ke area permukiman. Permukiman yang hampir tenggelam oleh luapan Bengawan Solo tahun 2007 itu sebagian besar memang permukiman yang berada pada bantaran sungai.

Secara kuantitatif peta tingkat risiko merupakan hasil perkalian antara tingkat bahaya dan tingkat kerentanan. Untuk lebih jelas mengenai agihan kelas risiko per kelurahan disajikan pada Tabel 9. Secara 
perhitungan hidrologi memang konsep pelurusan alur bertujuan untuk mempercepat aliran sungai menuju laut. Peningkatan debit akibat peningkatan kecepatan aliran telah diantisipasi dengan pelebaran alur dan pembuatan tanggul di sisi kakan kiri sungai. Namun secara ekologis konsep ini bertentangan dengan siklus hidrologi dimana seharusnya air hujan ditahan selama mungkin di darat untuk memenuhi kebutuhan kehidupan ekologi di darat, bukan secepat mungkin dialirkan ke laut.

\section{KESIMPULAN}

Teknologi Sistem Informasi Geografi dalam hal ini menggunakan perangkat lunak ArcView GIS 3.3 dengan ekstensi HEC-GeoRAS dan perangkat lunak hidrologi HEC-RAS mampu dimanfaatkan untuk pemodelan daerah rawan banjir akibat laupan Bengawan Solo di Kota Surakarta. Validasi pemodelan ini dilakukan dengan membandingkan tinggi muka air (TMA) atau kedalaman maksimum hasil pemodelan dengan kedalaman maksimum hasil perhitungan hidrologi dengan metode Gumbel. Hasil yang diperoleh perbedaan TMA hasil model dan hasil perhitungan berkisar antara $0,68 \%$ hingga $4,54 \%$ dengan rerata perbedaan $1,48 \%$ atau tingkat validasi mencapai $98,52 \%$.

Peta bahaya yang dihasilkan pada penelitian ini sebanyak delapan buah peta genangan hasil pemodelan dengan input berupa data debit puncak rancangan untuk periode ulang 10, 20, 40 dan 60 tahun berdasarkan data sebelum dan sesudah pelurusan. Berdasarkan perhitungan hidrologi tidak terbukti adanya perbedaan yang signifikan antara debit sebelum dan sesudah pelurusan. Dengan demikian pelurusan alur Bengawan Solo tidak berpengaruh terhadap debit. Data daerah rawan banjir atau peta bahaya yang selanjutnya akan digunakan untuk menghitung tingkat risiko yang digunakan dalam penelitian ini adalah peta bahaya hasil pemodelan dengan input debit paling tinggi yang pernah terjadi dan tercatat di Kota Surakarta, yaitu sebesar $2000 \mathrm{~m} 3 / \mathrm{s}$ yang terjadi tahun 1966 dan 2007 atau dengan data debit rancangan untuk periode ulang 60 tahun. Dari peta bahaya ini diketahui bahwa Kelurahan Sewu, Sangkrah, Semanggi, dan Pucangsawit mempuyai potensi bahaya banjir yang paling tinggi untuk wilayah Kota Surakarta dengan tinggi kedalaman genangan mencapai lebih dari tiga meter.

Peta tingkat risiko banjir dalam penelitian ini diturunkan dari hasil overlay antara peta tingkat bahaya dan peta tingkat kerentanan, dengan menggunakan perangkat lnak ArcView 3.3. Hasil yang didapat berupa peta kelas risiko banjir daerah pemodelan yang dikelompokkan menjadi empat kelas. Dari peta tingkat risiko ini diketahui bahwa Kelurahan
Sewu, Semanggi Sangkrah, dan Gandekan mempunyai potensi terkena risiko banjir tertinggi di Kota Surakarta.

\section{DAFTAR PUSTAKA}

Baiquni, M. (1988). Evaluasi Kapasitas Maksimum Sistem Drainase Terhadap Debit Banjir Rencana Tahun 2005 di Kotamadya Surakarta. Skripsi. Yogyakarta. Fakultas Geografi UGM.

BAKORNAS PB. (2005). Panduan Peneganalan Karakteristik Bencana dan Upaya Mitigasinya di Indonesia. Jakarta. BAKORNAS PB.

Chow, V.T. (1959). Open Chanel Hidarulics. (diterjemahkan oleh Suyatman dkk.) Hidrolika Saluran Terbuka. Jakarta. Erlangga.

Harto, S. (1985). Pengkajian Sifat Dasar Hidrograf Satuan Sungai-Sungai di Pulau Jawa untuk Perkiraan Banjir. Disertasi. Yogyakarta. UGM.

Harto, S. (1993). Analisis Hidrologi. Jakarta. Gramedia Pustaka Utama.

Hidayat, N. (2008). Citra Satelit dan Banjir Bengawan Solo. Lapan. Diakses pada 19 April 2009 dari http://bacatanda.wordpress.com/2008/02/24/citra-s atelit-dan-banjir-bengawan-solo/.

Kushartati, A. (2006). Pembuatan Peta Risiko Banjir sebagai Acuan Dasar Manajemen Bencana Alam Kawasan Sungai Gajah Wong di Kota Yogyakarta. Tesis. Yogyakarta. Fakultas Teknis UGM.

Liu, YB. dan kawan-kawan. (2004). Simulation of Flood Reduction by Natural River Rehabilitation Using a Distributed Hydrological Model. Hydrology and Earth System Science. 8(6). 1129-1140. EGU

Makruf. Mencermati Potensi Banjir Bengawan Solo. (2007). Diakses 11 Maret 2009 dari http://bpdas-solo.sim-rlps.dephut.go.id/index.php?

Manik, T. dkk. (___ __ Pemodelan Spasial Dinamis Untuk Informasi Potensi Banjir. Diakses pada tanggal $11 \quad$ Maret 2009 dari http://www.dirgantara-lapan.or.id/index.php? nama $=$ reinstra\&opt=detail\&id $=32$.

Marfai, M.A. (2003). GIS Modelling of River and Tidal Flood Hazard in the Waterfront City. Thesis. Netherland. ITC.

Marlena, N. (2010). Analisis Risiko Banjir Terhadap produktivitas Padi Menggunakan Teknik Penginderaan Jauh dan Sistem Informasi Geografi di DAS DengkengKabupaten Klaten Jawa Tengah. Tesis. Yogyakarta. Pascasarjana UGM.

Maryono, A. (2002). Eko-Hidraulik Pembagunan Sungai. Yogyakarta. Program Magister Sistem Teknik. Fakultas Teknik UGM.

Munawar. (2008). Penggunaan Citra Satelit Quickbird untuk Pengembangan Metode Penentuan Risiko Banjir di Daerah Perkotaan. Thesis. Yogyakarta. Program Pascasarjana UGM. 
Nugroho, S. P. (2002). Pemanfaatan Model Hidrologi untuk Penyusunan Sistem Perencanaan Pengendalian Banjir dalam Jurnal Alami. 7 (2).

Purwadi, D. (2000). Penggunaan Teknik Penginderaan Jauh dan Sistem Informasi Geografi Untuk Evaluasi Kerentanan Banjir di DAS Kening Kabupaten Tuban Provinsi Jawa Timur. Tesis. Yogyakarta. Pascasarjana UGM.

Setiaji, R. (2006). Pemetaan Daerah Rawan Banjir Dengan HEC-RAS di Sub-DAS Bogowonto Hilir. Skripsi. Yogyakarta. Fakultas Geografi UGM.

Setiyarso, B. (2009). Studi Reaksi Manusia Terhadap Bahaya Banjir Kota Surakarta. Skripsi. Surakarta. Fakultas Keguruan dan Ilmu Pendidikaan Universitas Sebelas Maret.

Setiawan, O. (2008). Analisis Risiko Banjir pada Daerah Aliras Sungai Babon. Semarang. Jawa Tengah. Tesis Yogyakarta. MPPDAS Fakultas Gografi UGM.

Seyhan, E. (1977). Mathematical simulation of Watershed Hydrologic Process. Utrecht. University of Utrecht.

Sinnakaudan, S. K. (2002). Flood Inundation Analysis Using HEC-6 and Arc View GIS 3.2a. University Science Malaysia. Engineering Campus. Penang Malaysia. Diakses pada tanggal 16 maret 2009 dari: http://redac.eng.usm.my/html/publish/2002_10.pdf Soewarno. (1995). Hidrologi. Aplikasi Metode Statistik untuk Analisa Data. Bandung. NOVA.

Sosrodarsono, S., Takeda, K. (1977). Hidrologi Untuk
Pengairan. Assosiation for International Technical Promotion. Japan. Tokyo.

Sudarmadji, S., \& Takeda, Kansaku. (2006) . Hidrologi untuk Pengairan. Jakarta. PT Pradnya Paramita.

Suroso. (2006). Kajian Kapasitas Sungai Logawa Dalam Menampung Debit Banjir Menggunakan Program HEC-RAS. Jurnal Teknik Sipil. Purwokerto. Volume III. Universitas Soedirman.

Tunas, I. G. (2004). Model Simulasi Sistem pengendalian Banjir dengan HEC-RAS dan SIG. Tesis. Yogyakarta. Teknik Sipil. Fakultas Teknik UGM.

USACE. (2001). HEC-RAS River Analysis System: User's Manual version 3.0 Hidrologic Engineering Center. USAGE (US Army of Engineers). USA. California.

USACE. (2002). HEC-GeoRAS an Extension for Support of HEC-RAS using ArcView. User's Manual version 3.1. USAGE (US Army of Engineers). USA. California.

USACE. (2002). HEC-RAS River Analysis System. User's Manual version 3.1. USAGE (US Army of Engineers). California.

USACE. (2005). HEC-GeoRAS GIS toos for Support of HEC-RAS using ArcGIS. User's Manual version 4. USAGE (US Army of Engineers). California.

Wood, M. (2007). Wentwort River Flood Hazarad Assassment. Envirinment Waikato Technical Report. Hamilton Easst New Zaeland. 